\title{
PEMBUATAN DISPENSER DESTILASI AIR LAUT SEBAGAI SARANA SUMBER AIR TAWAR UNTUK DAERAH PESISIR PANTAI
}

\author{
Engkos Koswara ${ }^{1}$, Nasim ${ }^{2}$ \\ Teknik Mesin \\ Universitas Majalengka \\ Jl. K.H. Abdul Halim No. 103 Majalengka \\ ekoswara.ek@gmail.com ${ }^{1}$
}

\begin{abstract}
Abstrak
Kebutuhan air nasional saat ini terkonsentrasi di Pulau Jawa dan Bali, dengan tujuan penggunaannya terutama untuk air minum, rumah tangga, perkotaan, industri, pertanian, dan lainnya. Dari data neraca air tahun 2003 dapat dilihat bahwa kebutuhan air pada musim kemarau di Pulau Jawa dan Bali yang sebesar 38,4 miliar meter kubik, hanya terpenuhi sekitar 25,3 miliar kubik atau hanya sekitar 66 persen. Defisit ini diperkirakan akan semakin tinggi pada tahun 2020, dimana jumlah penduduk dan aktifitas perekonomian meningkat secara signifikan. (Direktorat Pengairan dan Irigasi Bappenas, 2006).

Tanpa terkecuali daerah pesisir pantai juga sangat membutuhkan air bersih. Karena posisinya yang berada dengan laut, sangat mungkin terjadi intrusi air laut sehingga sumber air tawar akan terpengaruh oleh air laut. Oleh karena itu, daerah pesisir pantai sangat membutuhkan air tawar.

Dalam penelitian ini akan dikaji bagaimana membuat Dispenser Destilasi Air Laut sederhana yang dapat dimiliki oleh masing - masing rumah. Diharapkan dengan cara ini, tiap warga mempunyai fasilitas untuk penyedia air bersih.

Temperature tertinggi dari reaktor adalah $70^{\circ} \mathrm{C}$, terukur pada dinding reaktor. Pada temperature tersebut uap sudah mulai muncul. Untuk mencapai temperature $70^{\circ} \mathrm{C}$ dan mulai menghasilkan air destilasi membutuhkan waktu 14 menit. Produk hasil destilasi hanya terjadi pada efek 1, Efek 2 tidak menghasilkan produk. Hal demikian diakibatkan temperature efek 1 masih rendah sehingga tidak menghasilkan uap untuk efek 2 .
\end{abstract}

Kata kunci :

Kebutuhan Air Tawar, Pesisir Pantai, Dispenser Destilasi

\begin{abstract}
Currently, the national water demand is concentrated in Java and Bali, with the purpose of using it mainly for drinking water, household, urban, industrial, agricultural, and others. From the 2003 water balance data, it can be seen that the water demand in the dry season in Java and Bali, which amounted to 38.4 billion cubic meters, was only met by about 25.3 billion cubic meters or only about 66 percent. This deficit is expected to be even higher in 2020, where the population and economic activity will increase significantly. (Directorate of Irrigation and Irrigation Bappenas, 2006).

Without exception, coastal areas are also in dire need of clean water. Because of its position with the sea, it is very possible for sea water intrusion to occur so that freshwater sources will be affected by sea water. Therefore, coastal areas are in dire need of fresh water.

In this study, it will be studied how to make a simple Sea Water Distillation Dispenser that can be owned by each house. It is hoped that in this way, every citizen will have facilities to provide clean water.

The highest temperature of the reactor is $70^{\circ} \mathrm{C}$, measured on the reactor wall. At this temperature the steam has started to appear. To reach a temperature of $70^{\circ} \mathrm{C}$ and start producing distilled water takes 14 minutes. The product of distillation only occurs in 1st effect, 2nd Effect does not produce a product. This is because the temperature of 1 st effect is still low so it does not produce steam for 2 nd effect.
\end{abstract}

Keywords :

Fresh Water Needs, Coastal, Distillation Dispenser 


\section{Pendahuluan}

Kebutuhan air nasional saat ini terkonsentrasi di Pulau Jawa dan Bali, dengan tujuan penggunaannya terutama untuk air minum, rumah tangga, perkotaan, industri, pertanian, dan lainnya. Dari data neraca air tahun 2003 dapat dilihat bahwa kebutuhan air pada musim kemarau di Pulau Jawa dan Bali yang sebesar 38,4 miliar meter kubik, hanya terpenuhi sekitar 25,3 miliar kubik atau hanya sekitar 66 persen. Defisit ini diperkirakan akan semakin tinggi pada tahun 2020, dimana jumlah penduduk dan aktifitas perekonomian meningkat secara signifikan. (Direktorat Pengairan dan Irigasi Bappenas, 2006).

Tanpa terkecuali daerah pesisir pantai juga sangat membutuhkan air bersih. Karena posisinya yang berada dengan laut, sangat mungkin terjadi intrusi air laut sehingga sumber air tawar akan terpengaruh oleh air laut. Oleh karena itu, daerah pesisir pantai sangat membutuhkan air tawar.

Sumber air yang ada untuk daerah pesisir pantai adalah air laut. Hal demikian menjadi potensi besar dalah penanggulangan kebutuhan air tawar untuk kebutuhan warga sekita pesisir pantai. Akan tetapi, untuk mengubah air laut menjadi air tawar membutuhkan teknologi yang tidaklah murah.

Dalam penelitian ini, akan dikaji bagaimana apabila sebuah dispenser diubah menjadi alat destilasi air laut sederhana. Dispenser dipilih karena hampir tiap rumah memiliki alat dispenser tersebut, sehingga memungkinkan untuk tiap rumah memiliki alat yang diubah secara sederhana. Dengan batasan dispenser mempunyai slot pemanas air dan posisi galon berada di atas dispenser.

\section{KAJIAN LITERATUR}

\section{Destilasi Air Laut}

Proses desalinasi dengan cara destilasi adalah pemisahan air tawar dengan cara merubah phase air, sedangkan pada proses dengan membran yakni pemisahan air tawar dari air laut dengan cara pemberian tekanan dan menggunakan membran reverse osmosis atau dengan cara elektrodialisa. Di samping alat desalinasi itu sendiri, perlengkapan lainnya yang umum pada proses desalinasi adalah sistem intake air laut termasuk pompa intake, saringan kasar dan saringan halus, perpipaan air laut, perpipaan air hasil proses (air tawar) dan tangki penampungan, perlatan energi (listrik) dan sistem distribusi dan lain sebagainya. Beberapa jenis teknologi proses desalinasi air laut dapat dilihat pada gambar 1 .

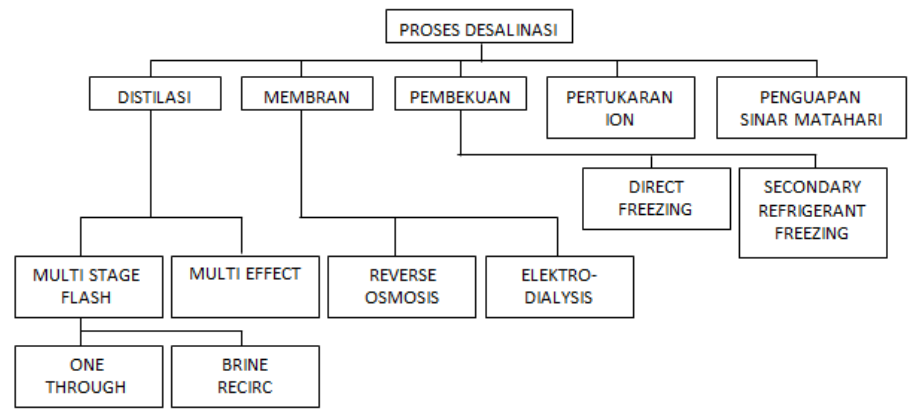

Gambar 1 Klasifikasi proses desalinasi air laut

Pemilihan proses yang akan digunakan harus disesuaikan dengan lokasi pengolahan, kualitas air laut, penggunaan air hasil pengolahan dan lain sebagainya berdasarkan studi kelayakan. Mengingat semakin bertambahnya permintaan air baik untuk kehidupan manusia maupun untuk industri, maka setiap negara perlu menyediakan air tawar yang murah walaupun biaya untuk pengadaan sumber energinya semakin tinggi. Di beberapa negara, penelitian dan pengembangan metode desalinasi, penambahan - penambahan baru, kombinasi dan lain sebagainya telah dilaksanakan untuk meningkatkan efisiensi dan pengolahan sistem desalinasi.

\section{Multi Effect Distilation}

Multi effect adalah suatu proses yang terdiri dari beberapa flash chamber yang disebut "effect". Dalam proses ini, hanya effect pertama yang dialiri uap dari boiler dan effect kedua dan selanjutnya memperoleh steam yang diproduksi oleh effect sebelumnya.

Dalam multi effect evaporator, air laut disemprotkan ke bagian luar dari tabung penukan panas yang diletakan secara horizontal. Pada saat uap air yang lebih panas yang terdapat dalam tabung berkondensasi dan menghasilkan air tawar, saat itu pula menyebabkan air laut diluar tabung mendidih, dan menghasilkan uap air baru yang kemudian mengalir ke tabung penukar panas berikutnya. Setiap effect mengurangi tekanannya dibawah tekanan jenuh dari temperatur brine (air laut yang pekat karena evaporasi).

Proses kondensasi dan evaporasi berulang ulang sejak dari effect pertama hingga effect terakhir. Dalam hal ini pengulangan evaporasi sesuai dengan nomer effect yang memproduksi air tawar dengan efisiensi panas tinggi. Gambar 2 memperlihatkan proses aliran pada multi effect evaporation. 


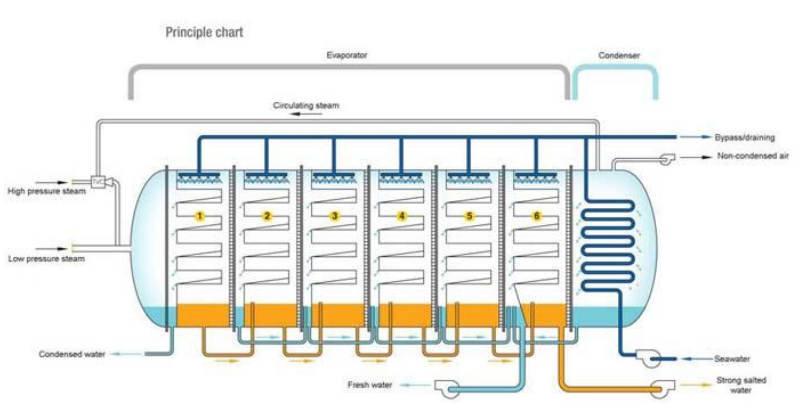

Gambar 2.2 Flow diagram desalinasi air laut dengan proses multi effect evaporation.

\section{METODE PENELITIAN}

Langkah - langkah dalam penelitian ini adalah sebagai berikut :

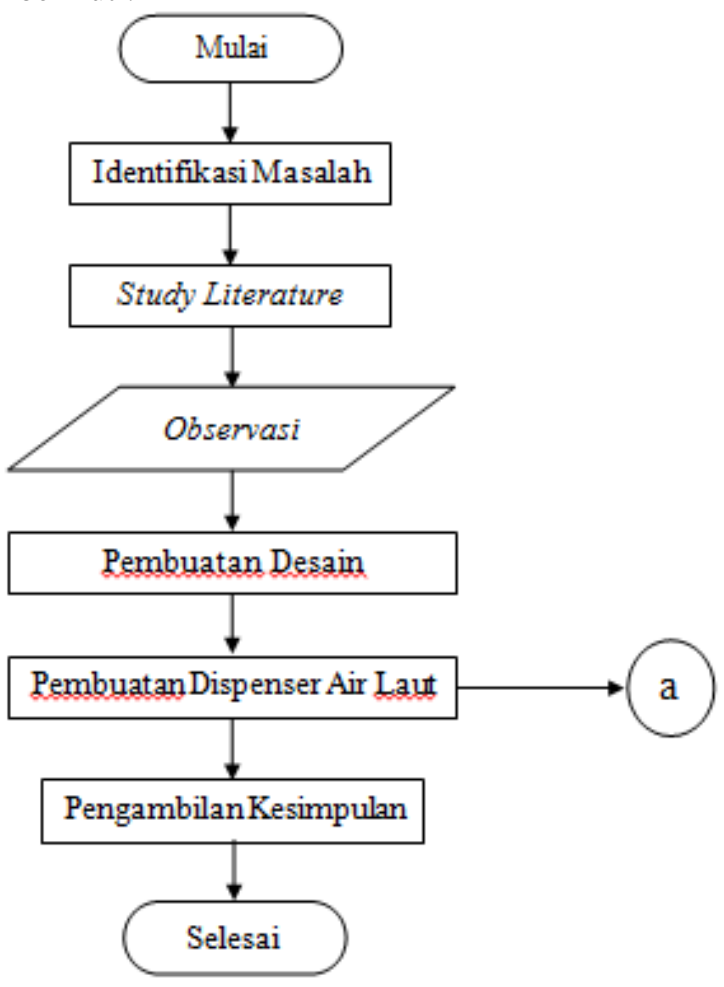

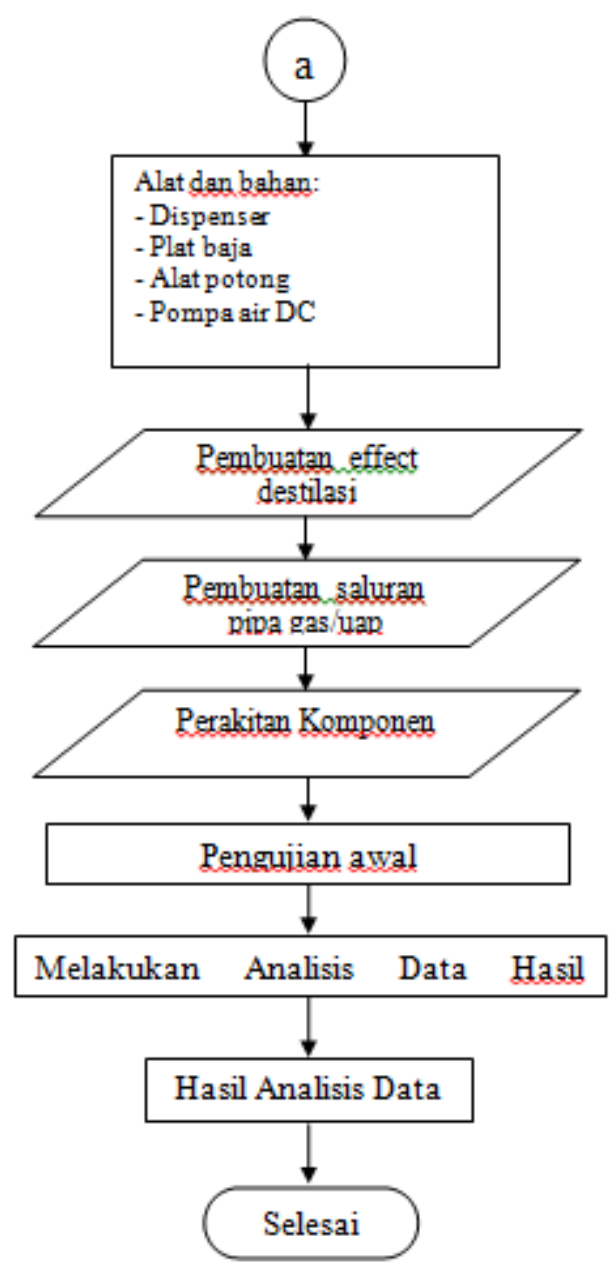

Penjelasan gambar 3.1 dan 3.2 diagram alir sistem penelitian dan diagram alir proses pengujian, diantaranya adalah sebagai berikut:

1. Identifikasi masalah dalam penelitian ini yaitu Desain dispenser sederhana dan mudah untuk diaplikasikan ditingkat rumah tangga, Desain effect destilasi, Study Literature

2. Study literature dilakukan dengan cara mempelajari buku, jurnal ilmiah dan skripsi terdahulu yang sesuai dengan topik penelitian, untuk memperoleh teori - teori dasar yang dapat digunakan sebagai rujukan untuk memperkuat argumen.

3. Observasi / Praktek Lapangan; Peneliti melakuan pengumpulan data dengan cara melakukan pengamatan secara langsung terhadap komponenkomponen yang akan diteliti pada Dispenser Destilasi.

4. Pembuatan desain; Pembuatan desain dilakukan menggunaka $\mathrm{CAD}$ untuk memudahkan dalam
Engkos Koswara, Nasim

Jurnal Ilmiah Teknologi Informasi Terapan

Volume 8, No 1, 15 Desember 2021 
proses pembuatannya. Pembuatan desain meliputi desain dispenser, jumlah effect, desain effect hingga saluran pipa gas/uap

5. Pembuatan Dispenser air laut meliputi Alat dan bahan, Pembuatan effect destilasi, Pembuatan saluran pipa gas/uap, Perakitan komponen, Pengujian awal, Melakukan analisis data hasil uji, Hasil analisis data, Pengambilan kesimpulan.

\section{HASIL DAN PEMBAHASAN}

\section{Pembuatan Desain Dispenser air laut}

Pembuatan desain menggunakan software solidwork untuk membantu memudahkan dalam pembuatan model awal. Dispenser yang digunakan merupakan jenis dispenser lantai dimana dispenser ini memiliki area yang cukup luas untuk menambahkan komponen tambahan dalam proses destilasi. Berikut merupakan desain awal dari skema destilasi air laut yang akan dibuat.

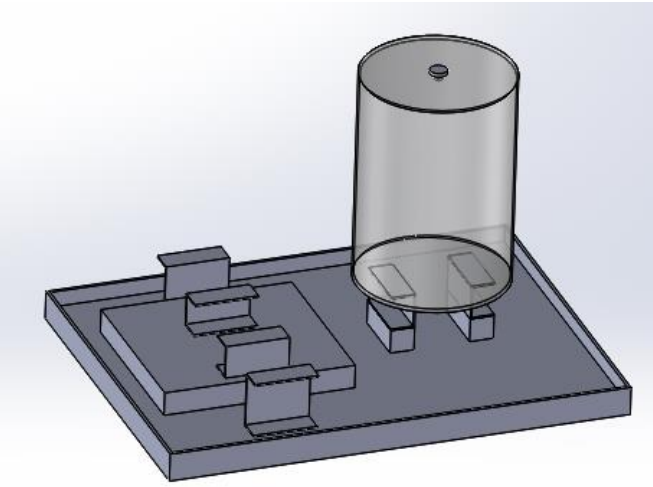

Gambar 5.1 kondisi awal isi dispenser dengan 1 pemanas

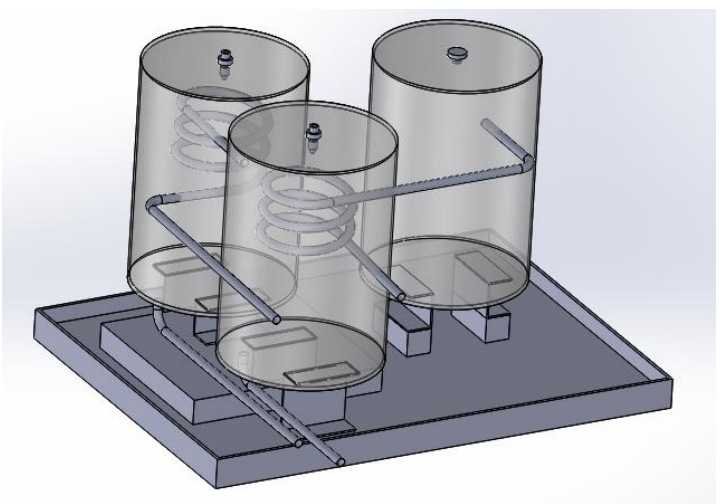

\section{Pembuatan Dispenser air laut} Alat dan bahan

- Dispenser

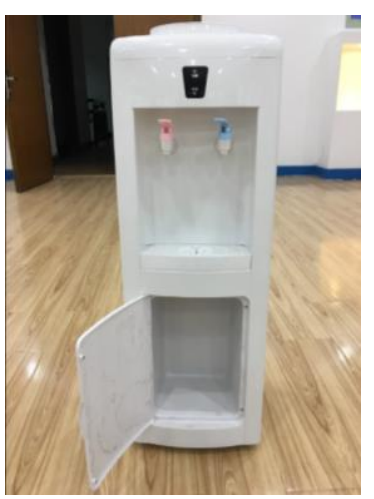

- $\quad$ Tabung heater

Tabung heater didapat dari bekas dispenser yang sudah tidak terpakai.

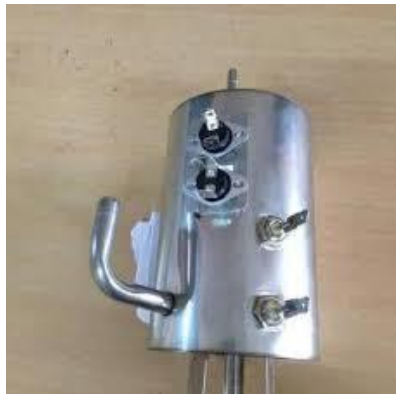

- $\quad$ Pipa tembaga

Pipa tembaga digunakan karena memiliki daya hantar panas yang baik. Pipa tembaga tersebut dibuat dengan membentuk spiral untuk memaksimalkan luas hantaran yang diperoleh.

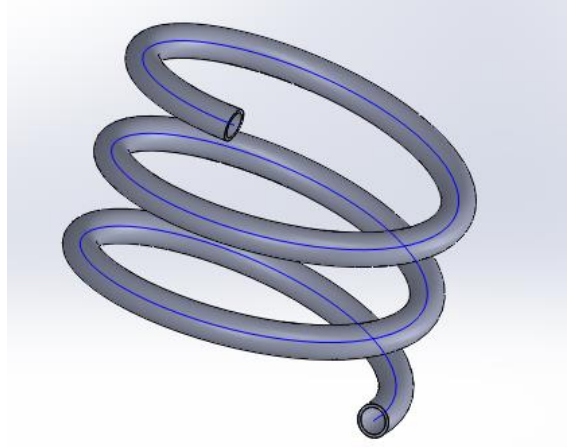

Gambar 5.2 Desain awal dispenser destilasi dengan 3 effect 2 output 
- $\quad$ Nozzle

spray nozzle menggunakan nozzle yang sering digunakan oleh green house dengan ukuran lubang $0,5 \mathrm{~mm}$.

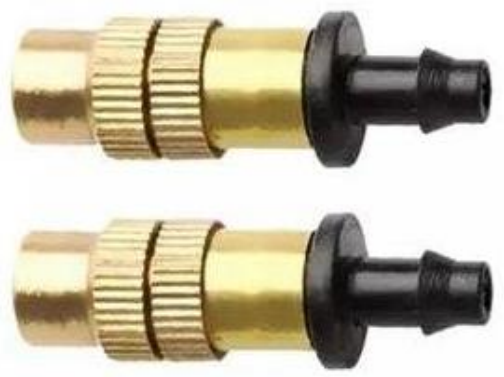

\section{Selang}

Selang menggunakan selang spray green house sesuai dengan nozzle yang digunakan dengan ukuran selang $7 \mathrm{~mm}$.

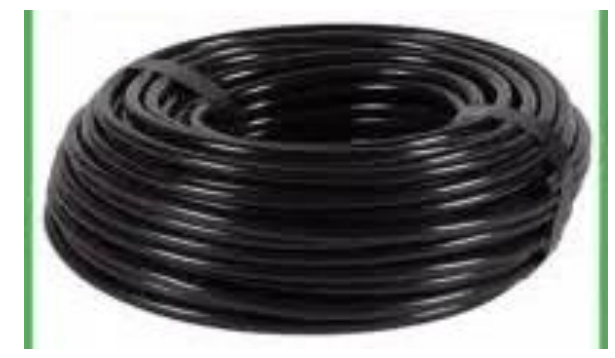

- Pompa DC

Pompa DC digunakan karena harga relative murah dan tidak memakan ruang

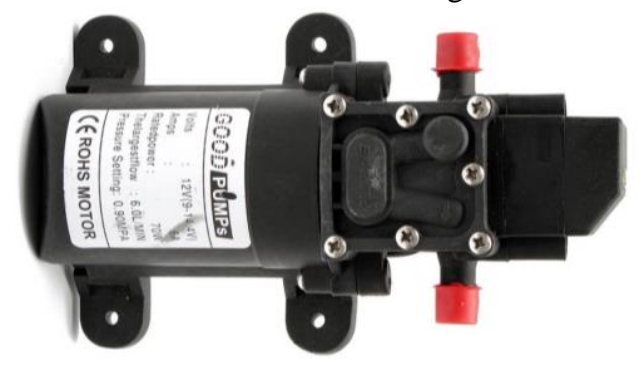

- Refractometer

Refractometer digunakan untuk mengukur kadar garam air laut sebelum dan sesuai proses destilasi menggunakan dispenser destilasi.

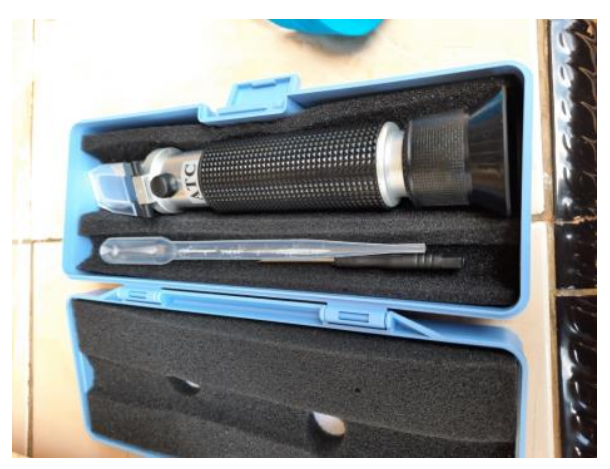

\section{Pembuatan Effect Destilasi}

Effect destilasi dibuat dari tabung heater dispenser bekas yang sudah tidak terpakai. Modifikasi tabung heater dibutuhkan untuk membuat tabung heater menjadi effect destilasi. Tabung heater tersebut ditambahkan pipa tembaga yang dibuat spiral dan menambahkan nozzle pada masing-masing effect untuk membantu effect destilasi menghasilkan uap baru pada masing - masing effect. Seperti terlihat pada gambar berikut.

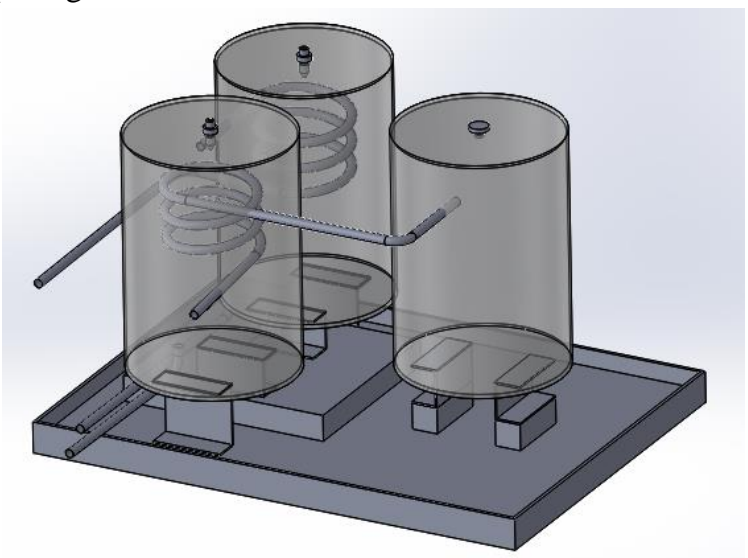




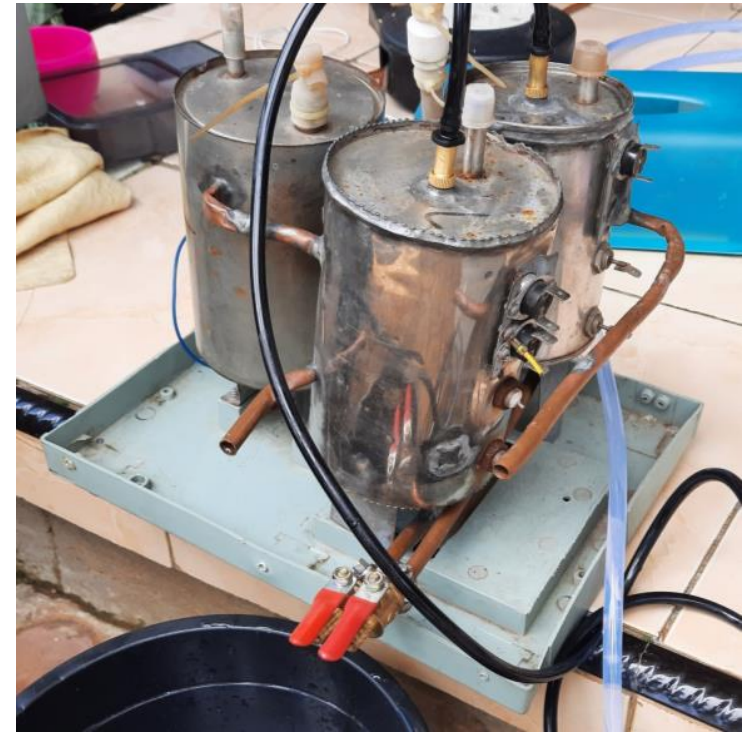

\section{Perakitan Komponen}

Proses perakitan dilakukan untuk menggabungkan komponen effect dengan body dispenser, hal tersebut penting dilakukan mengingatk produk ini harus dalam bentuk utuh dispenser air galon.

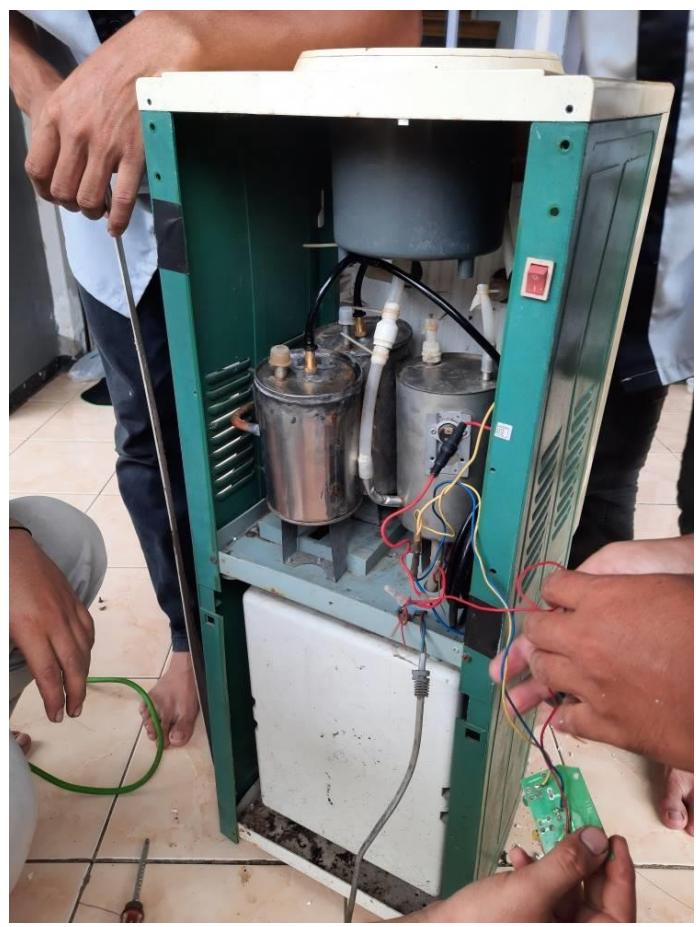

\section{Pengujian}

Pengujian dilakukan untuk memastikan alat yang telah dibuat mampu mengubah air laut menjadi air tawar. Pengujian alat dilihat berdasarkan waktu dan temperature yang terjadi pada saat pengujian. Berikut merupakan prosedur pengujian yang telah dilakukan.

- Masukan air pada reactor sebanyak setengah volume reactor

- Panaskan reactor dengan cara menghubungkan sumber arus listrik

- Apabila temperature sudah mencapai $70 \square \mathrm{C}$, nyalakan pompa nozzle spray untuk tabung efek 1 dan 2

- Tampung air yang keluar dari tabung efek 1 dan 2

- Selalu cek kondisi level air pada tabung reactor, jangan sampai kosong

- Matikan pompa nozzle spray

- Matikan sumber arus reactor panas.

Berikut merupakan hasil uji pompa dispenser.

\begin{tabular}{|l|c|c|l|}
\hline No. & $\begin{array}{c}\text { Waktu Uji } \\
\text { (menit) }\end{array}$ & $\begin{array}{c}\text { Temperatur } \\
\left({ }^{\circ} \mathrm{C}\right)\end{array}$ & Keterangan \\
\hline 1 & 0 & 30 & $\begin{array}{l}\text { Pengisian air pada } \\
\text { reactor panas }\end{array}$ \\
\hline 2 & 14 & 70 & $\begin{array}{l}\text { Reactor mencapai } \\
\text { temperature } 70^{\circ} \mathrm{C} \\
-\begin{array}{l}\text { Reactor menghasilkan } \\
\text { uap }\end{array}\end{array}$ \\
\hline 3 & 15 & 70 & $\begin{array}{l}\text { - Pompa spray nozzle } \\
\text { dinyalakan } \\
\text { Tetesan air destilasi } \\
\text { mulai diproduksi dari } \\
\text { efek 1 }\end{array}$ \\
\hline
\end{tabular}

Engkos Koswara, Nasim

Jurnal Ilmiah Teknologi Informasi Terapan

Volume 8, No 1, 15 Desember 2021 
Berikut merupakan hasil produk menurut alat refraktometer.

Sebelum air baku masuk ke dispenser air laut (dilakukan uji refraktormeter) air baku memiliki salinitas sebesar $20 \%$.

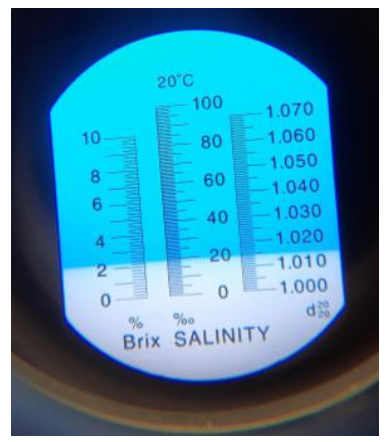

Setelah air baku keluar dari dispenser air laut (dilakukan uji refraktormeter) air baku memiliki salinitas sebesar $0 \%$.

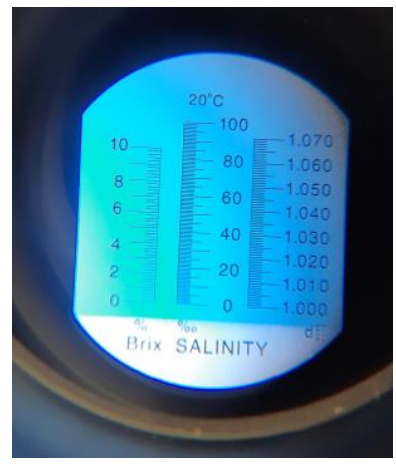

\section{Analisis data hasil pengujian}

Pengujian awal menunjukan beberapa analisa, diantaranya :

- Penggunaan termokopel bawaan dispenser menghambat laju pemanasan reaktor. Hal demikian ditujukan dengan temperature reaktor hanya menyentuh angka $50 \square \mathrm{C}$, Sehingga dalam pengujian tidak disertakannya termokopel.

- Temperature tertinggi dari reaktor adalah $70^{\circ} \mathrm{C}$, terukur pada dinding reaktor. Pada temperature tersebut uap sudah mulai muncul.

- Untuk mencapai temperature $70^{\circ} \mathrm{C}$, membutuhkan waktu 14 menit.

- Produk hasil destilasi hanya terjadi pada efek 1, Efek 2 tidak menghasilkan produk. Hal demikian diakibatkan temperature efek 1 masih rendah sehingga tidak menghasilkan uap untuk efek 2.

\section{KESIMPULAN DAN SARAN}

Terdapat beberapa hal yang dapat disimpulkan dari hasil penelitian yang telah dilakukan, diantaranya

- Desain dispenser air laut cukup sederhana. Tidak banyak ubahan yang dilakukan, hanya penambahan reactor sebagai efek dari destilasi dan tidak digunakannya termokopel pada reactor panas.

- Desain efek pada dispenser destilasi tidak terlalu rumit. Tabung efek dibuat dari reactor yang sama yang digunakan pada dispenser hanya dilakukan penambahan pipa spiral dan nozzle untuk efek destilasinya.

\section{UCAPAN TERIMA KASIH}

Pemberian penghargaan yang setinggi-tingginya dan ucapan terima kasih kepada Universitas Majalengka melalui P3M sesuai dengan perjanjian Penugasan Program Penelitian Internal Universitas Majalengka Tahun 2020.

\section{REFERENSI}

Artin Hatzikioseyian, Roza Vidali, Pavlina Kousi, "Modelling And Thermodynamic Analysis Of A Multi Effect Distillation (Med) Plant For Seawater Desalination", National Technical University of Athens (NTUA) GREECE.

Hisham El-Dessouky, "Steady-State Analysis of the Multiple Effect Evaporation Desalination Process"

O. A. Hamed, "Thermal performance and exergy analysis of a thermal vapor compression desalination system", Department od Chemical and Petroleum Engineering, Faculty of Engineering, U.A.E. University. Philadelphia, 1995.

Hisham El-Dessouky,"Analysis of single effect evaporator desalination system combined with vapor compression heat pump", 
Chemical Engineering Department, Kuwait University, 1997.

Manal A. Sorour, "Optimization of Multiple Effect Evaporators Designed for Fruit Juice Concentrate", Food Eng. and Packaging Dept., Food Tech. Res. Institute, Agric. Res. Center, Giza, Egypt, 2015. 